\title{
Nitrogen Uptake and Growth of Irrigated Rice as Affected by Nitrogen Rates ${ }^{1,2}$
}

\author{
Servando Silva and José Vicente Chandler ${ }^{3}$
}

\begin{abstract}
Rice fertilized with 50,100 and $150 \mathrm{~kg}$ of $\mathrm{N} /$ ha produced $5.0,6.9$ and $7.8 \mathrm{t} /$ ha, respectively, of dry rough rice. Maximum uptake of $\mathrm{N}$ was 90,124 , and 148 $\mathrm{kg} / \mathrm{ha}$ at the respective rates. At the rate of $100 \mathrm{~kg}$ of $\mathrm{N} / \mathrm{ha}$, uptake of $\mathrm{N}$ by the entire rice plant, including roots, was about $20 \mathrm{~kg} / \mathrm{ha}$ during the first 4 weeks, $60 \mathrm{~kg} /$ ha during the following 2 weeks, and $40 \mathrm{~kg} / \mathrm{ha}$ during the remainder of the cropping period. The $\mathrm{N}$ levels had no residual effects on a subsequent rice crop. About $66 \%$ of the first $50 \mathrm{~kg} / \mathrm{ha}$ increment of $\mathrm{N}$ applied and $50 \%$ of the second increment were recovered in the rice plants in this experiment conducted in lysimeter tanks, with no losses by leaching.
\end{abstract}

\section{INTRODUCTION}

About 200,000 t of rice are consumed yearly in Puerto Rico but until recently none was grown commercially on the island.

Since 1969 considerable research has been conducted on intensive rice production in Puerto Rico, including the testing of numerous varieties and determining the effects of planting season, pesticide applications, irrigation practices and fertilization on yields (7).

Growth pattern and $\mathrm{N}$ uptake by rice plants vary widely with varieties, climate, soil type, method of cultivation, and amount of nutrients applied $(1,4)$. Tanaka (6) found widely different $\mathrm{N}$ uptake rates by early maturing (110 days) and late maturing (150 days) varieties, and Lockhard (2) found wide differences, attributable to ecological conditions and cultural systems in $\mathrm{N}$ uptake by rice plants. Therefore, although growth rates and uptake by rice have been studied in numerous experiments throughout the world, the results obtained are not directly applicable to Puerto Rico's new rice industry.

In Puerto Rico, Ramirez et al. (5) found that rice growing on a Vertisol responded to $\mathrm{N}$ application rates of up to $220 \mathrm{~kg} / \mathrm{ha}$. Lozano and Abruña (3) found that rice responded to $\mathrm{N}$ application rates of up to $200 \mathrm{~kg} / \mathrm{ha}$ when the $\mathrm{N}$ was applied at planting, but responded only to the $100 \mathrm{~kg} /$ ha rate, producing just as high yields as with the higher rates, when the $\mathrm{N}$ used was divided into two equal applications, one at planting and one 6 weeks later. No studies have been conducted in Puerto Rico on the

${ }^{1}$ Manuscript submitted to Editorial Board October 5, 1983.

${ }^{2}$ This paper covers work carried out cooperatively between the Agricultural Research Service, USDA and the Agricultural Experiment Station, University of Puerto Rico, Rio Piedras, P.R.

${ }^{3}$ Agricultural Technician and Soil Scientist, respectively, Agricultural Research Service, USDA. 
growth rates of or the uptake of $\mathrm{N}$ by flooded, intensively managed rice.

This paper presents the results of a study conducted to determine the growth rate of the entire rice plant, including roots, and the uptake of $\mathrm{N}$ at three $\mathrm{N}$ levels under soil and climatic conditions typical of the rice growing area of Puerto Rico, with intensive, modern cultural practices.

\section{MATERIALS AND METHODS}

The experiment was conducted at Rio Piedras using 28 concrete lysimeter tanks, each of which was $2.4 \mathrm{~m}$ long by $1.2 \mathrm{~m}$ wide by $45 \mathrm{~cm}$ deep. The tanks are filled with Coloso clay loam (Aeric Tropic Fluvaquents), which, over a period of several years, had become compacted to a bulk density $\left(1.2 \mathrm{~g} / \mathrm{cm}^{3}\right)$ similar to that normally found in the field.

Before this experiment, an unfertilized rice crop was grown in all the plots. Similar yields, averaging 3,000 kg of rough rice/ha, were obtained in all plots, indicating that $\mathrm{N}$ levels were similarly low in all of them.

The soil in all plots was worked to a depth of $15 \mathrm{~cm}$ and $30 \mathrm{~kg}$ of P/ha and $100 \mathrm{~kg}$ of $\mathrm{K} / \mathrm{ha}$ were applied. Seed of the Mars variety was planted at the rate of $120 \mathrm{~kg} / \mathrm{ha}$ on March 20,1982, and covered with about $2 \mathrm{~cm}$ of soil. The plots were irrigated by flooding them periodically as required over the next 3 weeks. Propanil ${ }^{4}$ was then applied and 2 days later the plots were flooded to a depth of $10 \mathrm{~cm}$. They were kept flooded until 2 weeks before harvesting. Insects and diseases were controlled by spraying with malathion and Benomyl (applied as Benlate), respectively, as required.

Nitrogen rates tested were 50,100 and $150 \mathrm{~kg} / \mathrm{ha}$, applied as ammonium sulphate. Half of each rate was applied 1 week after planting and the remainder 5 weeks later. All treatments were replicated nine times in a randomized block design.

Starting 4 weeks after planting, and every 2 weeks thereafter, the rice plants in a $20 \times 120 \mathrm{~cm}$ area in one-half of each plot were carefully dug up and separated into stems plus leaf sheaths, panicles when they emerged, and roots, which were washed on a screen. All sections were dried and weighed, and their $\mathrm{N}$ content was determined by the Kjeldahl method.

Yields were determined in the remaining half of each plot about 16 weeks after planting. All plots were then planted again to rice, which received no $\mathrm{N}$ fertilizer to determine whether any difference existed in the amounts of residual nitrogen remaining in the different plots.

\footnotetext{
${ }^{4}$ Trade names are used in this publication solely to provide specific information. Mention of a trade name does not constitute a guarantee or warranty of the product by the U.S. Department of Agriculture or an endorsement by the Department and the Agricultural Experiment Station, Univ. P.R. over other products not mentioned.
} 


\section{RESULTS AND DISCUSSION}

Rice fertilized with 50,100 , and $150 \mathrm{~kg}$ of $\mathrm{N} / \mathrm{ha}$ produced yields averaging 5.0, 6.9 and $7.8 \mathrm{t} / \mathrm{ha}$, respectively, of dry rough rice.

As figure 1 shows, $\mathrm{N}$ uptake by the entire rice plant was very low during the first 4 weeks, very high during the following 2 weeks, and increased at a reduced rate during the following 4 weeks. After that time

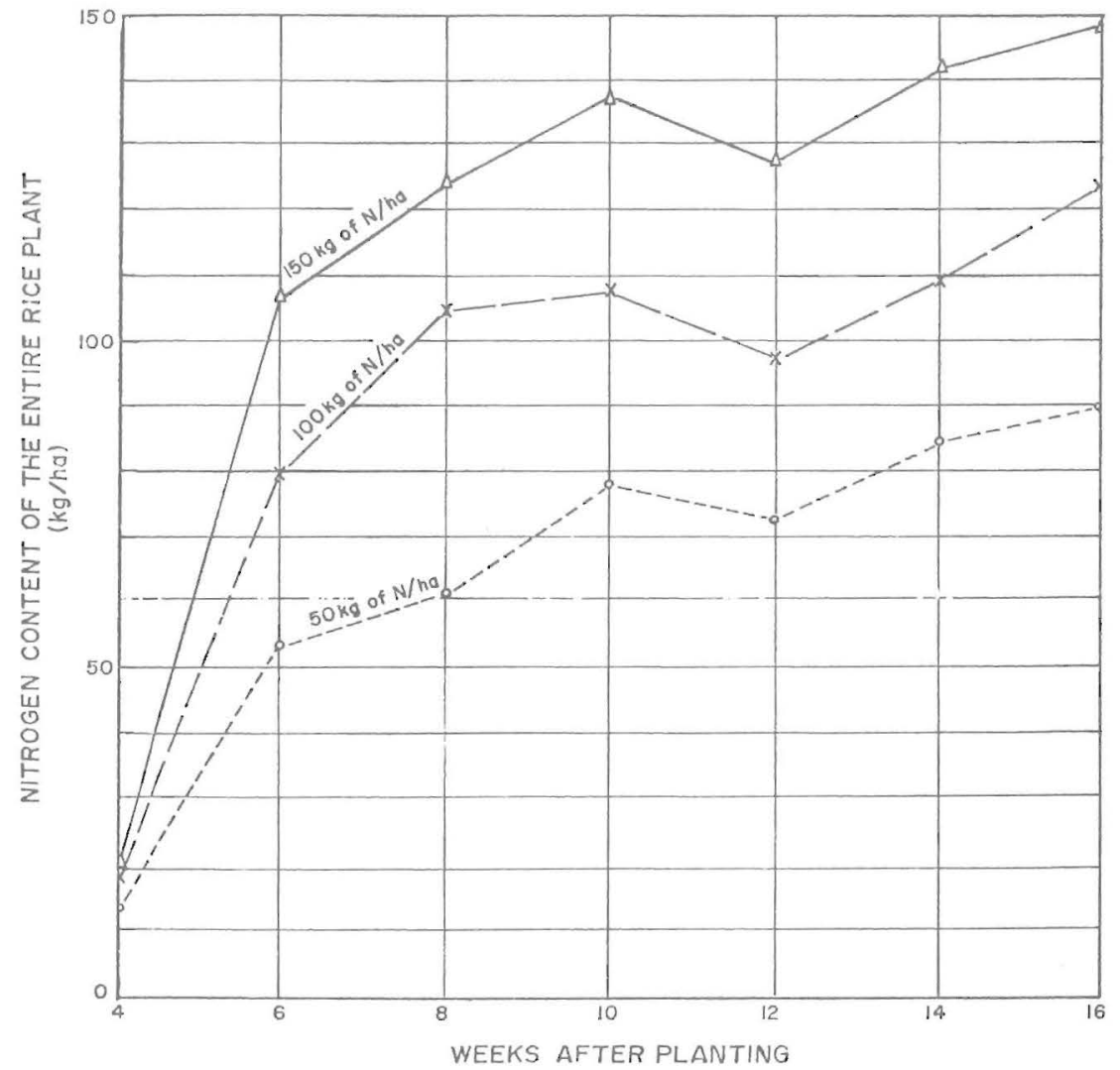

FIG. 1.-Uptake of nitrogen by intensively managed flooded rice at three levels of fertilization.

little $\mathrm{N}$ was taken up by the rice plants. At the $100-\mathrm{kg} / \mathrm{ha}$ rate, about 20 $\mathrm{kg}$ of $\mathrm{N}$ was taken up/ha during the first 4 weeks, 60 during the following 2 weeks, and 40 during the remainder of the cropping period.

The maximum amount of $\mathrm{N}$ taken up by the rice plants increased with each level of $\mathrm{N}$, totaling 90,124 and $148 \mathrm{~kg}$ of $\mathrm{N} / \mathrm{ha}$ at the respective 50 , 100 , and $150 \mathrm{~kg} /$ ha rate of $\mathrm{N}$ fertilization. Uptake exceeded the amount of $\mathrm{N}$ applied due to the $\mathrm{N}$ supplied by the soil. 
The percentage of $\mathrm{N}$ content of the rice plants decreased rapidly with age (fig. 2). At the highest and medium rates of $\mathrm{N}$ fertilization, $\mathrm{N}$ content averaged about $4 \% 4$ weeks after planting then decreased to about $1.6 \%$ 4 weeks later and to about $0.8 \%$ over the following 4 weeks, after which it remained fairly constant.

At the medium rate of fertilization, $\mathrm{N}$ content of the leaves was about $5 \%$ at 4 weeks, then decreased to about $1.8 \% 6$ weeks later and to about

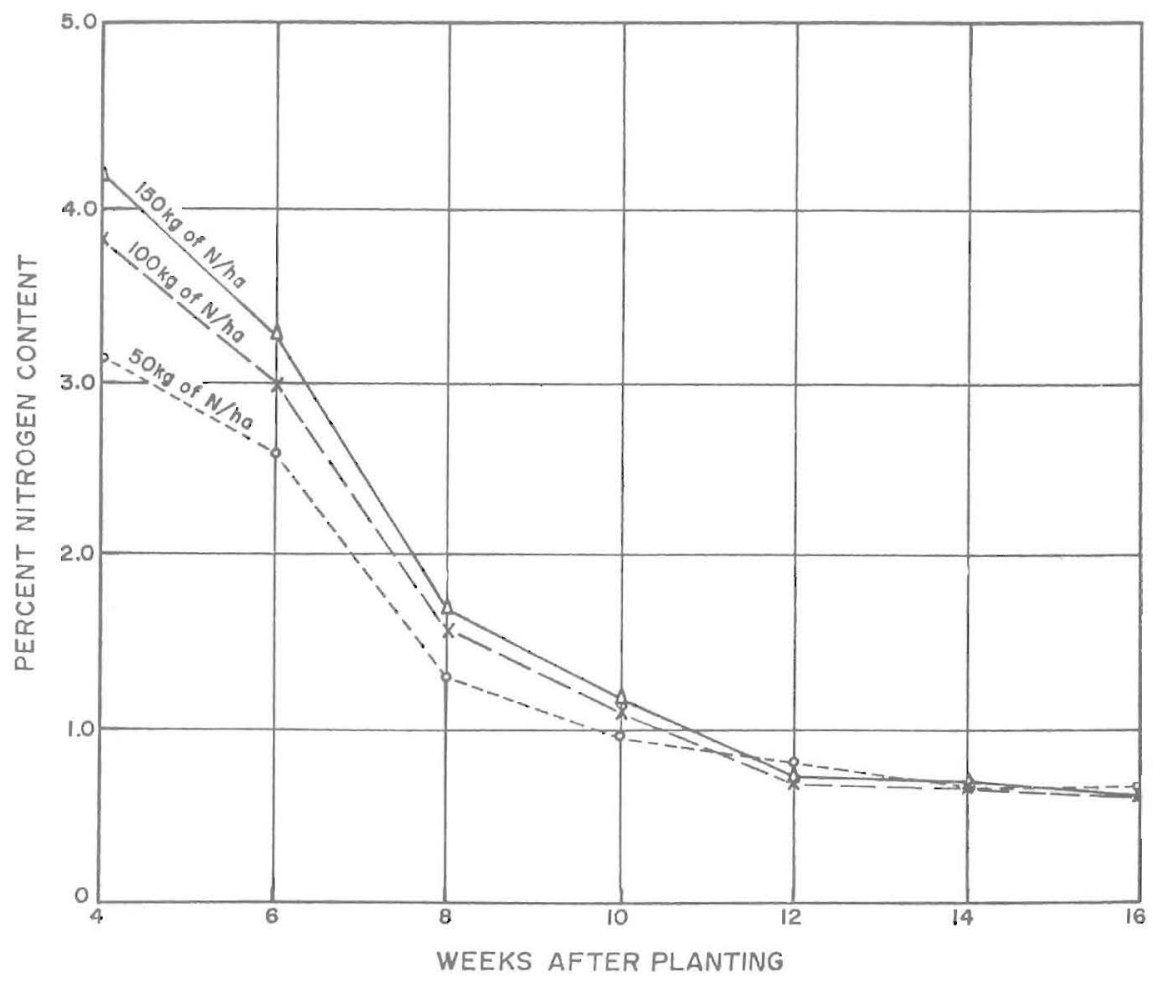

FIG. 2.-Percent nitrogen content of the total rice plants as affected by nitrogen rates and stage of growth.

$0.7 \%$ at harvest time (fig. 3 ). The $\mathrm{N}$ content of stems and roots was much lower at 4 weeks than that of the leaves and decreased more gradually than that of the leaves until about 10 weeks following planting. Then they remained fairly constant at about $0.5 \%$. Nitrogen content of the panicles remained constant at about $0.8 \%$ from emergence to harvest time. The different parts, especially the leaves, have a high concentration of $\mathrm{N}$ during the early stages of growth. Then, as the rice plants age the concentration decreases as the plants continue to grow without taking up substantially more $\mathrm{N}$. 
As figure 4 illustrates, the stems and leaves grew rapidly from 4 weeks to about 10 weeks after planting. Then the stems ceased to grow, and the dry weight of the leaves declined slowly. The panicles, which emerged about 12 weeks after planting, grew very rapidly during the following 2 weeks. The roots grew little after about the first 8 weeks after planting. The rice plants as a whole grew at a fast, steady rate from 4 weeks after planting up to about 16 weeks.

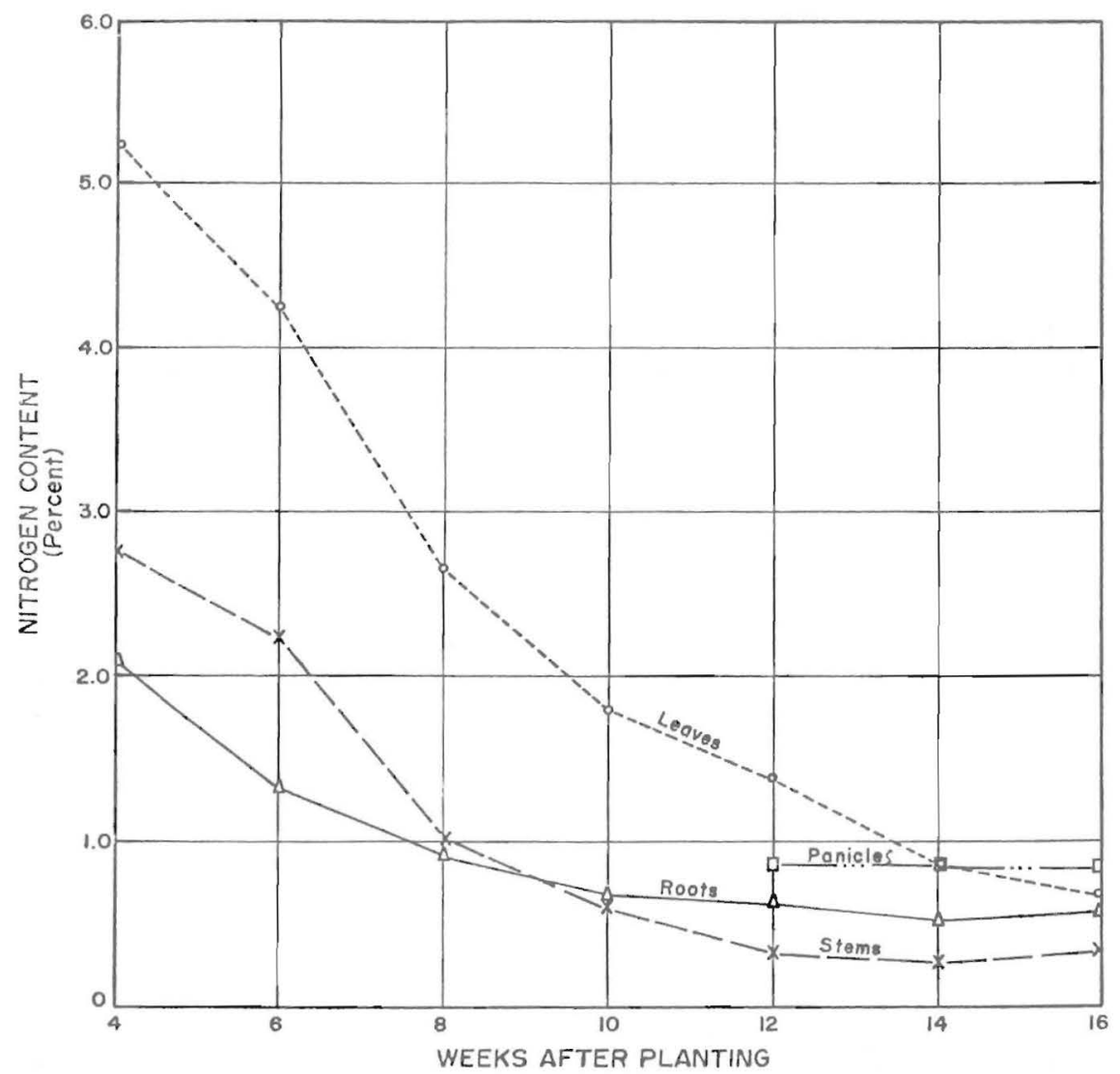

FIG. 3.-Percent nitrogen content of different parts of the rice plants at difference ages (100 kg of $\mathrm{N}$ applied/ha).

Under the conditions of this experiment, rice took up about $15 \%$ of the $\mathrm{N}$ used during the first 4 weeks after planting, $55 \%$ during the following 2 weeks, $22 \%$ during the next 4 weeks and $8 \%$ during the remainder of the season. Therefore, intensively managed, high-yielding rice that produces a crop in about 120 days should be heavily fertilized with $\mathrm{N} 3$ to 4 weeks after planting. At that time the rice is well established, 


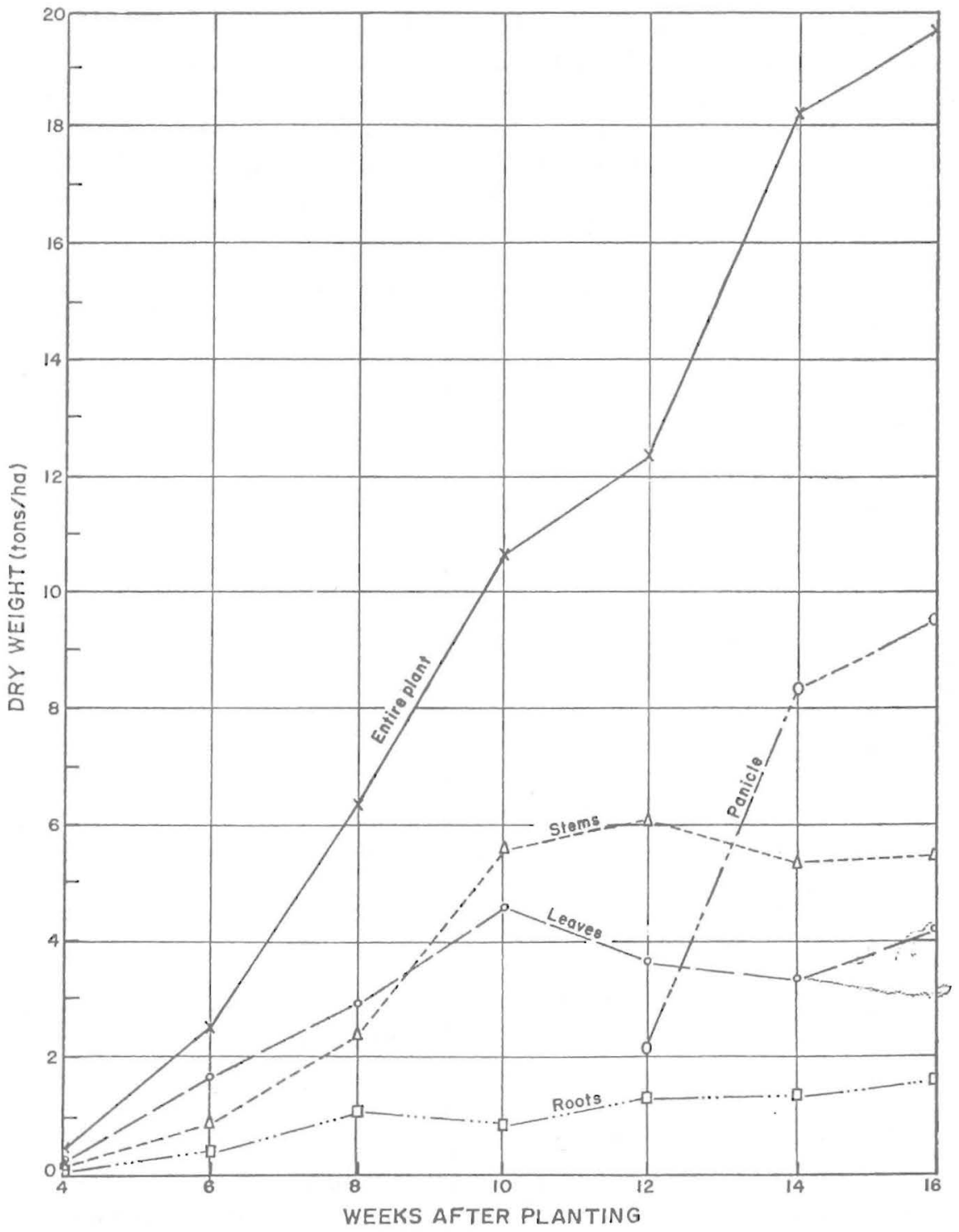

FIG. 4.-Growth rates of various parts of well-fertilized, intensively managed flooded rice (100 kg of $\mathrm{N} / \mathrm{ha}$ ).

weeds have been controlled, and the fields have been flooded. Then the rice should be given a second, lighter application of $\mathrm{N}$ about 3 weeks later. If heavy $\mathrm{N}$ rates are used, about $20 \%$ of the $\mathrm{N}$ can be incorporated into the soil at planting to reduce $\mathrm{N}$ losses and to give the crop an initial boost, $60 \%$ should be applied 4 weeks after planting, and the remainder should be applied 3 weeks later. 
The subsequent crop of rice, which received no $\mathrm{N}$ fertilizer, evidenced no residual effect of the $\mathrm{N}$ applications and yielded an average of only $2.5 \mathrm{t}$ of rough rice/ha. Therefore, since no leaching losses could have occurred in the lysimeter tanks, apparently all of the $\mathrm{N}$ applied during the course of the experiment was either used by the rice crop or lost by volatilization.

Recovery of the $\mathrm{N}$ applied as fertilizer can be estimated from figure 1. Uptake of $\mathrm{N}$ by the rice plants was $33 \mathrm{~kg} / \mathrm{ha}$ more at the application rate of $100 \mathrm{~kg} / \mathrm{ha}$ than at the rate of $50 \mathrm{~kg} / \mathrm{ha}$ indicating that about $66 \%$ of the first $50 \mathrm{~kg} / \mathrm{ha}$ increment of $\mathrm{N}$ was recovered in the rice plants. Similarly, $50 \%$ of the next $50 \mathrm{~kg} / \mathrm{ha}$ increment of $\mathrm{N}$ was recovered. These recovery rates are about twice as high as those found under field conditions by Lozano and Abruña (3). Possible explanations for the lower recovery rates in their studies are that $\mathrm{N}$ could have been lost by leaching under field conditions and that $\mathrm{N}$ in the roots was not measured.

\section{RESUMEN}

Se determinó en los distintos órganos de la planta de arroz cuánto nitrógeno usa, cuánto la planta crece y cuánto nitrógeno contiene cuando se cultiva intensivamente.

Se produjeron 5.0, 6.9 y 7.8 toneladas de arroz seco en cáscara/ha cuando se abonó con 50, 100 y $150 \mathrm{~kg}$ de nitrógeno/ha, respectivamente.

Las plantas, incluyendo las raíces, utilizaron 90, 124 y $148 \mathrm{~kg}$ de nitrógeno/ha cuando se aplicaron 50, 100 y $150 \mathrm{~kg}$ de nitrógeno/ha, respectivamente. Cuando se aplicaron $100 \mathrm{~kg}$ de nitrógeno/ha, el arroz utilizó $20 \mathrm{~kg}$ de nitrógeno durante las primeras 4 semanas después de la siembra, $60 \mathrm{~kg} / \mathrm{ha}$ durante las próximas 2 semanas y $40 \mathrm{~kg} / \mathrm{ha}$ más hasta la cosecha.

Es evidente que el arroz debe de abonarse abundantemente con nitrógeno aproximadamente 4 semanas despues de la siembra, cuando ya está bien establecido y se han controlado los yerbajos e inundado los campos. Si se aplican niveles altos de nitrógeno debe de incorporarse alrededor del $20 \%$ en el suelo al sembrarse, alrededor de $60 \% 4$ semanas más tarde y el remanente unas 3 semanas después.

El nitrógeno aplicado no produjo efecto residual sobre la cosecha subsiguiente. Se recuperó alrededor del $66 \%$ del primer incremento de nitrógeno aplicado y alrededor del $50 \%$ del segundo incremento en este experimento en que no ocurrieron pérdidas por lixiviación, dado que se realizó en tanques lisímetros.

\section{LITERATURE CITED}

1. Ishizuka, Y., 1964. Nutrient uptake by rice at different stages of growth. The Mineral Nutrition of the Rice Plant, International Rice Research Institute, Johns Hopkins Press, Baltimore, Md., Chapter 13, p. 199-217. 


\section{JOURNAL OF AGRICULTURE OF UNIVERSITY OF PUERTO RICO}

2. Lockhard, R. G., 1959. Mineral nutrition of the rice plant in Malaya. Federation of Malaya Min. Agric. Bull. 108, p. 1-148.

3. Lozano, J. and F. Abruña, 1981. Nitrogen rates in single and split applications and yield of flooded rice. J. Agric. Univ. P.R. 65 (1) 35-41.

4. Matsushima, S., 1964. Nitrogen requirements at different stages of growth. The Mineral Nutrition of the Rice Plant, International Rice Research Institute, Johns Hopkins Press, Baltimore, Md., Chapter 14, p. 219-42.

5. Ramírez, C. T., F. Abruña, J. Lozano and J. Vicente-Chandler, 1975. Effect of fertilizer on yields of three varieties of rice at two locations in Puerto Rico, J. Agric. Univ. P.R. 56 (1): 1-4.

6. Tanaka, A., S. Patnaik and C. T. Abichandani, 1959. Studies on the nutrition of rice plants. Proc. Indian Acad. Sci. 49 (4): 146-54 and 217-26.

7. Vicente-Chandler, J., F. Abruña, J. Lozano, S. Silva, A. Rodriguez and C. T. Ramírez, 1977. Cultivo intensivo y perspectivas del arroz en Puerto Rico, Bol. 250, Esta. Exp. Agric. Univ. P.R. 